\title{
Erratum to: Vascular endothelium protective property of curcumin
}

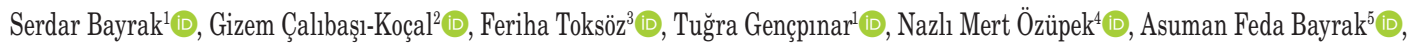
Ezgi Daşkın ${ }^{6}$, Yasemin Başbınar² (D)

${ }^{1}$ Department of Cardiovascular Surgery, Dokuz Eylül University, Faculty of Medicine, Izmir, Turkey ${ }^{2}$ Department of Translational Oncology, Dokuz Eylül University, Institute of Oncology, Izmir, Turkey ${ }^{3}$ Dokuz Eylül Technology Development Zone, Tailor of Science Innovation Biotechnology Inc, Izmir, Turkey ${ }^{4}$ Department of Basic Oncology, Dokuz Eylül University, Institute of Health Sciences, Izmir, Turkey

${ }^{5}$ Department of Otolaryngology, Katip Çelebi University, Atatürk Training and Research Hospital, Izmir, Turkey

${ }^{6}$ Department of Translational Oncology, Dokuz Eylül University, Institute of Health Sciences, Izmir, Turkey

In the funding section of the manuscript entitled "Vascular endothelium protective property of curcumin" published in the pages of 121-126, Volume 30, Issue 2 in 2021 of the Turkish Journal of Vascular Surgery, the project number was erroneously written. The following statement is the correct statement of funding:

"This work was supported by DEU Scientific Research Coordination Unit. Project Number: 2018.KB.SAG.048."

We sincerely apologize to the readers for this inconvenience.

Yours sincerely,

Prof. Serdar Bayrak, MD

Published online: July 30, 2021

Correspondence: Serdar Bayrak, MD. Dokuz Eylül Üniversitesi Tıp Fakültesi Kalp ve Damar Cerrahisi Anabilim Dalı, 35340 İnciraltı, İzmir, Türkiye. e-mail: drbayrakserdar@gmail.com 